\title{
Essential Role of the fosB Gene in Molecular, Cellular, and Behavioral Actions of Chronic Electroconvulsive Seizures
}

\author{
Noboru Hiroi, ${ }^{1}$ Gerard J. Marek, ${ }^{1}$ Jennifer R. Brown, ${ }^{2}$ Hong Ye, ${ }^{2}$ Frederic Saudou, ${ }^{2}$ Vidita A. Vaidya, ${ }^{1}$ \\ Ronald S. Duman, ${ }^{1}$ Michael E. Greenberg, ${ }^{2}$ and Eric J. Nestler ${ }^{1}$ \\ 1 Laboratory of Molecular Psychiatry, Departments of Psychiatry and Neurobiology, Yale University School of Medicine, \\ New Haven, Connecticut 06508, and 2Division of Neuroscience, Children's Hospital and Department of Neurobiology, \\ Harvard Medical School, Boston, Massachusetts 02115
}

The role of Fos-like transcription factors in neuronal and behavioral plasticity has remained elusive. Here we demonstrate that a Fos family member protein plays physiological roles in the neuronal, electrophysiological, and behavioral plasticity associated with repeated seizures. Repeated electroconvulsive seizures (ECS) induced isoforms of $\triangle F$ FosB in frontal cortex, an effect that was associated with increased levels of the NMDA receptor 1 (NMDAR1) glutamate receptor subunit. Induction of $\triangle F o s B$ and the upregulation of NMDAR1 occurred within the same neurons in superficial layers of neocortex. Activator protein-1 (AP-1) complexes composed of $\Delta$ FosB were bound to a consensus $\mathrm{AP}-1$ site in the 5'-promoter region of the NMDAR1 gene. The upregulation of NMDAR1 was absent in mice with a targeted disruption of the fosB gene. In addition, repeated ECS treatment caused progressively shorter motor seizures (tolerance) in both rats and wild-type mice, as well as reduced NMDA-induced inward currents in pyramidal neurons from superficial layers of the neocortex of wild-type mice. These behavioral and electrophysiological effects were also significantly attenuated in fos B mutant mice. These findings identify fos $\mathrm{B}$ gene products as transcription factors critical for molecular, electrophysiological, and behavioral adaptations to motor seizures.

Key words: transcription factor; seizure; ECS; cerebral cortex; c-Fos; FosB; $\triangle$ FosB; FRA; JunD; AP-1; neural plasticity; depression; epilepsy; NMDA receptor
The long-term responses of the brain to chemical and electrical stimulation have served as useful models to gain insight into the molecular mechanisms underlying neural plasticity (Hyman and Nestler, 1993). Increasing evidence suggests that transcriptional regulation of genes is one pivotal mechanism of plasticity. As a result, identification of transcription factors whose induction is required for neuronal and behavioral adaptations to chemical and electrical stimulation is a critical step in understanding complex forms of neural plasticity in the brain.

Different types of seizures are dynamic behavioral manifestations of excessive activation of distinct brain regions. Electroconvulsive seizures (ECS) depend on activation of the motor cortex, whereas most chemically induced seizures occur, at least initially, via activation of limbic structures (McNamara, 1994). In addition to inducing changes in behavior, repeated ECS are associated with a number of neurochemical changes in relevant brain regions (e.g., Hiroi et al., 1996; Nibuya et al., 1996), with little sign of neuronal cell loss (Devanand et al., 1994). Thus, the ECS paradigm is a model to study the roles of transcription factors in

Received Feb. 5, 1998; revised June 19, 1998; accepted June 23, 1998

This work was supported by United States Public Health Service Grants MH51399 to E.J.N. and HD18655 and NS28829 to M.E.G. and by grants from the National Alliance for Research on Schizophrenia and Depression and the Abraham Ribicoff Research Facilities, State of Connecticut Department of Mental Health and Addiction Services. We thank Drs. M. Iadarola, M. Gruda, and R. Bravo for their generous gifts of antibodies and Dr. M. Picciotto for her valuable comments on this manuscript.

Correspondence should be addressed to Dr. Eric J. Nestler, Department of Psychiatry, Yale University School of Medicine, 34 Park Street, New Haven, CT 06508.

Dr. Hiroi's present address: Laboratory of Molecular Psychobiology, Departments of Psychiatry and Neuroscience, Albert Einstein College of Medicine, Bronx, NY 10461.

Copyright (C) 1998 Society for Neuroscience $\quad 0270-6474 / 98 / 186952-11 \$ 05.00 / 0$ activity-dependent plasticity. Yet, in contrast to limbic seizures (see McNamara, 1994; Watanabe et al., 1996), the molecular factors involved in ECS are poorly understood.

Considerable attention has focused on the transcription factor products of the fos and jun families of immediate-early genes, which are induced rapidly but transiently in the brain in response to acute seizure (Morgan and Curran, 1991a). Such transcription factors are believed to then regulate the expression of specific late-response genes, which would lead to some of the functional and structural adaptations to the original stimulus. Indeed, Fos and Jun proteins bind to AP-1 (activator protein-1) sites, which have been found in the $5^{\prime}$-promoter regions of genes that encode certain peptide neurotransmitters, receptors, protein kinases, and other intracellular signaling molecules (see Sheng and Greenberg, 1990; Hughes and Dragunow, 1995). Although some of these potential target genes can be regulated by AP-1 complexes in vitro, it has not yet been possible to demonstrate a physiological target gene for these transcription factors in the brain in vivo. Moreover, whereas several Fos and Jun family member proteins are induced acutely, there is evidence that their induction desensitizes after chronic perturbation (Winston et al., 1990; Hope et al., 1992, 1994a,b; Pennypacker et al., 1995).

We have demonstrated previously that repeated ECS induce a long-lasting AP-1 complex in cerebral cortex that is composed of novel Fos-like proteins of 35-37 kDa, termed "chronic FRAs" (Fos-related antigens) (Hope et al., 1994b). Persistent induction of the chronic FRAs and the associated chronic AP-1 complex is in marked contrast to the very short-lived induction of several Fos-like proteins and the acute AP-1 complex by an acute seizure (Sonnenberg et al., 1989).

The aims of the present study were to characterize further the 
chronic FRAs and the chronic AP-1 complex in response to repeated ECS and then to identify potential target genes for this transcription factor and its role in electrophysiological and behavioral adaptations to ECS.

\section{MATERIALS AND METHODS}

Animal treatments. We used male Sprague Dawley rats (200-350 gm; Camm Research Institute, Wayne, NJ) and fos B mutant mice and their age-matched wild-type littermates (2-3 months old) (Brown et al., 1996). Animals were divided into five groups. One group received sham treatments for 6-7 d and was killed $18-20 \mathrm{hr}$ after the last sham treatment. A second group received sham treatments for $6-7 \mathrm{~d}$ and was killed 2 or 6 hr after acute ECS treatment $(45 \mathrm{~mA}$ and $0.3 \mathrm{sec}$ for the rat; $9 \mathrm{~mA}$ and $0.3 \mathrm{sec}$ for the mouse) on the last day. A third group received daily ECS treatments for 6-7 d and was killed $18-20 \mathrm{hr}$ after the last treatment. In a separate time-course experiment, a fourth group was given sham treatment for $6 \mathrm{~d}$ and killed 18-20 hr later or given sham treatment for $5 \mathrm{~d}$ and a single ECS on the 6th day and killed 18-20 hr later. A fifth group received sham or ECS treatments for $2 \mathrm{~d}$ and was killed $24 \mathrm{hr}$ after the last treatment. This group was used for electrophysiology.

Tissue preparation. Animals were decapitated, and the frontal cortex was isolated by gross dissection. The sample was the entire frontal cortex, including the medial prefrontal and motor cortex. Brain samples were Dounce-homogenized in electrophoretic mobility shift assay buffer ("EMSA buffer") (Korner et al., 1989; Hope et al., 1994a): $20 \mathrm{~mm}$ HEPES, pH 7.9, $0.4 \mathrm{~m} \mathrm{NaCl}, 20 \%$ glycerol, $5 \mathrm{~mm} \mathrm{MgCl}_{2}, 0.5 \mathrm{~mm}$ EDTA, $0.1 \mathrm{~mm}$ EGTA, 1\% Nonidet P-40, $10 \mu \mathrm{g} / \mathrm{ml}$ leupeptin, $0.1 \mathrm{~mm}$ $p$-aminobenzamide, $1 \mu \mathrm{g} / \mathrm{ml}$ pepstatin, $0.5 \mathrm{~mm}$ PMSF, and $5 \mathrm{~mm}$ DTT. Homogenates were incubated on ice for $30 \mathrm{~min}$ and were centrifuged at $12,000 \times g$ for $20 \mathrm{~min}$ at $4^{\circ} \mathrm{C}$. Supernatants were used for Western blotting and gel shift assays.

Immunoblotting. Aliquots of tissue extracts (containing $50 \mu \mathrm{g}$ of protein) were diluted in EMSA buffer containing 2\% SDS and $\beta$-mercaptoethanol and were subjected to SDS-PAGE (6.5 or $10 \%$ acrylamide $/ 0.4 \%$ bis-acrylamide in resolving gels) at $75 \mathrm{~V}$ overnight. Proteins were transferred electrophoretically to polyvinylidene fluoride membranes (Immobilon-P; Millipore, Bedford, MA). Membranes were then incubated with 1 or $2 \%$ nonfat dry milk in $10 \mathrm{~mm}$ sodium phosphate buffer (PBS) for $60 \mathrm{~min}$ at room temperature and in primary antiserum overnight at $4^{\circ} \mathrm{C}$. Membranes were washed and incubated with goat anti-rabbit or horse anti-mouse $\operatorname{IgG}$ peroxidase conjugate $(1: 4000$ or 1:2000, respectively; Vector Laboratories, Burlingame, CA) for $2 \mathrm{hr}$. After washing in PBS, membranes were developed by chemiluminescence (Renaissance; DuPont NEN, Boston, MA). We used an anti-FRA antiserum (1:4000; Dr. M. J. Iadarola, National Institutes of Health) as described previously (Young et al., 1991; Hope et al., 1994a). This antiserum was raised against a sequence highly conserved in all known Fos family member proteins (DNA binding domain). An excess amount of the immunogen eliminated specific FRA bands. The other antibodies we used were a monoclonal anti-NMDA receptor 1 (anti-NMDAR1) antibody (1:4000; PharMingen, San Diego, CA), a polyclonal antiNMDAR2A affinity-purified antibody (1:1000; Chemicon, Temecula, $\mathrm{CA}$ ), and a polyclonal anti-NMDAR2B affinity-purified antibody (1:1000; Chemicon). The specificity of these antibodies has been established (Brose et al., 1994; Siegel et al., 1994; Snell et al., 1996), and these antibodies recognized specific bands at their predicted molecular weights. Levels of subunit immunoreactivity were quantified by use of a Macintosh-based image analysis system with National Institutes of Health software. Immunoblots were routinely stained by amido black to confirm equal loading and transfer of proteins.

Gel shift assay. Gel shift assays were performed according to published procedures (Hope et al., 1994b). We used double-stranded oligonucleotides, which contained the AP-1 site from the human metallothioneine II gene (5'-TCGACGTGACTCAGCGCGC-3') (Sonnenberg et al., 1989) or the AP-1 site from the rat NMDAR1 gene (5'-GATCAAGCCTGAGTCACAG-3') (Bai and Kusiak, 1993). (The bold nucleotides indicate double-stranded sequences; the underlined nucleotides indicate the consensus AP-1 site.) The probes were radioactively labeled with $\left[\alpha-{ }^{32} \mathrm{P}\right] \mathrm{dGTP}$ and $\left[\alpha-{ }^{32} \mathrm{P}\right] \mathrm{dTTP}$ using Klenow DNA polymerase fill-in reaction. Protein $(20$ or $40 \mu \mathrm{g})$ was mixed with the probes and incubated for $20 \mathrm{~min}$ at room temperature. Samples were then electrophoresed in a nondenaturing gel system that contained $6 \%$ acrylamide $/ 0.24 \% N, N^{\prime}-$ methylene-bis-acrylamide, $25 \mathrm{~mm}$ Tris-borate, $\mathrm{pH} 8.3,1 \mathrm{~mm}$ EDTA, and $1.6 \%$ glycerol as described previously (Hope et al., 1994a). Specificity of the resulting AP-1 binding activity was demonstrated by competition with nonradioactive probe and mutant probe (data not shown) (see also Hope et al., 1994b) as well as by supershift assays.

Supershift assays were conducted in the same manner as gel shift assays except for the addition of antiserum as described (Hope et al., 1994b). Briefly, $1 \mu \mathrm{l}$ of antiserum against c-Fos, FosB/AFosB, FRA-1, FRA-2, c-Jun, JunB, or JunD (1:30 or 1:3) was added to samples in reaction buffer $(29 \mu \mathrm{l})$. These antibodies were provided by M. Gruda and R. Bravo of Bristol-Myers Squibb (Princeton, NJ). Samples were incubated with antiserum for $2 \mathrm{hr}$ at room temperature. One microliter of radioactively labeled double-stranded AP-1 probe (Sonnenberg et al., 1989) was then added, and the mixture was incubated for $20 \mathrm{~min}$ at room temperature. The specificity of these antisera has been well characterized, and each has been shown to disrupt successfully AP-1 binding activity of complexes containing the specific proteins at the concentrations used here (Gruda et al., 1996).

Anatomical procedures. For in situ hybridization, rat brains were removed rapidly from decapitated animals, immediately frozen on dry ice, and cut at $10 \mu \mathrm{m}$. Sections were fixed for $5 \mathrm{~min}$ in $4 \%$ paraformaldehyde, were washed for $10 \mathrm{~min}$ in PBS, and were immersed for $30 \mathrm{~min}$ in $2 \times$ SSC $(0.3 \mathrm{M} \mathrm{NaCl}$ and $30 \mathrm{~mm}$ sodium citrate). Buffer $(500 \mu \mathrm{l})$ containing $2 \times$ $10^{6} \mathrm{cpm}$ of an oligoprobe directed against NMDAR1 mRNA (antisense, 5' -TTCСТCСТCСТCСТCACTGTTCACCTTGAATCGGCCAAAGGGACT-3'; sense, 5'-AGTCCCTTTGGCCGATTCAAGGTGAACAGTGAGGAGGAGGAGGAA-3') or an oligoprobe directed against NMDAR2B (antisense, 5'-GGGCCTCCTGGCTCTCTGCCATCGGCTAGGCACCTGTTGTAACCC-3'; sense, 5'-GGGTTACAACAGGTGCCTAGCCGATGGCAGAGAGCCAGGAGGCCC-3') was placed onto each slide. Sections were incubated overnight at $37^{\circ} \mathrm{C}$. Sections were rinsed for $2 \mathrm{hr}$ in $1 \times \mathrm{SSC}$ and for $1 \mathrm{hr}$ in $0.5 \times \mathrm{SSC}$ at room temperature. After the last wash for $1 \mathrm{hr}$ in $1 \times \mathrm{SSC}$ at $37^{\circ} \mathrm{C}$, sections were dried and exposed to Hyperfilm- $\beta$-max. The optical density of mRNA signals was measured from film using a Macintoshbased image analysis system with National Institutes of Health software. For each section, rectangular areas $(1 \times 0.3 \mathrm{~mm})$ were chosen from the superficial (II and III) and deep (V and VI) layers of the rat motor cortex. Measurements were taken from both hemispheres of the entire extent of the motor cortex, using standards provided by $\mathrm{Na}$ tional Institutes of Health software. For each rat, the entire extent of motor cortex, represented by two to three levels in the anterior-posterior axis of sections, was examined on both hemispheres. These in situ hybridization experiments were repeated on two to three sets of tissue sections. As a result, quantification of in situ hybridization data was based on analysis of $\sim 50$ determinations of sham- and of ECS-treated tissue.

For standard immunohistochemistry, mice and rats were anesthetized with sodium pentobarbital at $120 \mathrm{mg} / \mathrm{kg}$ and were perfused with $0.9 \%$ saline followed by $4 \%$ paraformaldehyde. Brains were post-fixed for $1-2$ $\mathrm{hr}$ in $4 \%$ paraformaldehyde and were cryoprotected in $20 \%$ glycerol overnight. Mouse sections were cut at $20 \mu \mathrm{m}$ and were incubated with a monoclonal antibody against calbindinD $\mathrm{D}_{28 \mathrm{~K}}(1: 1000$; Sigma, St. Louis, MO) or a monoclonal antibody against NMDAR1 (1:1000; PharMingen). Sections were incubated with a biotinylated horse anti-mouse IgG (1:500) and stained with ABC-DAB (Hiroi, 1995; Hiroi and Graybiel, 1996). Similarly, rat brain sections were stained with the polyclonal anti-FRA antibody (1:5000) and biotinylated rabbit $\operatorname{IgG}(1: 500)$. For each section, rectangular areas $(1 \times 0.3 \mathrm{~mm})$ were chosen from the superficial (II and III) and deep (V and VI) layers of the motor cortex. The number of immunoreactive nuclei was counted inside the rectangular areas as described (Hiroi and Graybiel, 1996). The specificity of these various antibodies has been well characterized (Brose et al., 1994; Huntley et al., 1994; Siegel et al., 1994; Hiroi and Graybiel, 1996).

For double-labeling immunofluorescence, rat and mouse brain sections were incubated for $10 \mathrm{~min}$ with $1 \%$ Triton $\mathrm{X}-100$, for $30 \mathrm{~min}$ with $5 \%$ normal goat serum, and overnight with a mixture of a monoclonal antibody against NMDAR1 (1:1000; PharMingen) and the polyclonal anti-FRA antibody (1:5000) or polyclonal anti-FosB/ $\Delta$ FosB antibody (1:1000; Santa Cruz Biotechnology, Santa Cruz, CA). Sections were then incubated with a mixture of fluorescein-conjugated goat anti-mouse IgG (1:100; Jackson Laboratories, Burlingame, CA) and Texas redconjugated goat anti-rabbit IgG (1:500; Jackson Laboratories). Resulting sections were examined by confocal microscopy. Adsorption of the antiFRA antibody with the immunogen eliminated staining. The selectivity of the anti-NMDAR1 antibody and the anti-FosB/ $\Delta$ FosB antibody has been established previously (Huntley et al., 1994; Siegel et al., 1994; 
Hiroi and Graybiel, 1996); in addition, omission of the primary antibodies eliminated staining. The selectivity of the secondary antibodies and their lack of cross-reactivity have been well characterized (Berhow et al., 1996).

Some brain sections of wild-type and fos B mutant mice were analyzed by use of a standard Nissl-staining procedure described elsewhere (Hiroi, 1995).

Behavioral analysis. The duration of motor seizures elicited by ECS treatments was assessed in rats and in fos B mutant and wild-type mice. Assessments were performed by an observer blinded to the genotypes of the mice. Motor seizure was defined as full-body extension and repetitive, jerky paw-leg movements. Sham-treated rats and mice received ear clips without any current passed.

Electrophysiology. Brain slices were prepared from male fos $\mathrm{B}$ mutant mice $(n=15)$ and their age-matched wild-type littermates $(n=13)(2-3$ months old) (Brown et al., 1996). Briefly, a cervical dislocation was performed, in adherence to protocols approved by the Yale University Animal Care and Use Committee. After decapitation, the brain was removed rapidly and placed in an ice-cold modified artificial CSF (ACSF) in which sucrose $(252 \mathrm{~mm}$ ) was substituted for $\mathrm{NaCl}$ (Aghajanian and Rasmussen, 1989). A block of the brain containing the motor cortex was dissected free, and coronal slices $(500 \mu \mathrm{m})$ were cut with an oscillating-blade tissue slicer (FHC, Brunswick, ME). Slices were then transferred to the stage of a fluid-gas interface chamber that had a constant flow of humidified $95 \% \mathrm{O}_{2} / 5 \% \mathrm{CO}_{2}$. The chamber was heated slowly from room temperature to $34^{\circ} \mathrm{C}$. The slices were perfused with normal ACSF that consisted of (in $\mathrm{mM}$ ): $\mathrm{NaCl} 126 ; \mathrm{KCl} \mathrm{3} ; \mathrm{CaCl}_{2} 2$; $\mathrm{MgSO}_{4} 2 ; \mathrm{NaHCO}_{3} 26 ; \mathrm{NaH}_{2} \mathrm{PO}_{4}$ 1.25; and D-glucose 10. The ACSF flow rate was $1.5 \mathrm{ml} / \mathrm{min}$. There was a $2 \mathrm{hr}$ recovery period before experiments.

Intracellular recording and single-electrode voltage clamping were conducted in neocortical layer II/III pyramidal cells using an Axoclamp 2-A (Axon Instruments, Foster City, CA). Stubby electrodes $(\sim 8 \mathrm{~mm}$, shank to tip) with relatively low capacitance and resistance $(40-60 \mathrm{M} \Omega$ ) were pulled from filament-containing capillary tubing $(1.5 \mu \mathrm{m})$ with a Brown-Flaming electrode puller (Sutter Instruments, San Rafael, CA) and were filled with $1 \mathrm{~m}$ potassium acetate. Under voltage clamp, electrodes prepared in this manner had rapid settling times $(50-75 \mu \mathrm{sec})$, allowing switching frequencies of $4-6 \mathrm{~Hz}$ and a loop gain of $10 \mathrm{nA} / \mathrm{mV}$ ( $30 \%$ duty cycle). Phase lag was used to prevent oscillations; false clamping was avoided by using optimal capacitance neutralization and by allowing settling to a horizontal baseline, verified by monitoring input voltage continuously. NMDA $(6.25-50 \mu \mathrm{M})$ was bath-applied for $1.5 \mathrm{~min}$, and the steady-state inward current was monitored. Cells were clamped at $-55 \mathrm{mV}$ to decrease $\mathrm{Mg}^{2+}$ block of the NMDA responses. Pyramidal cells were identified according to criteria described previously (McCormick et al., 1985; Connors and Gutnick, 1990). Regularly spiking layer II/III pyramidal cells were recorded in the motor cortex. Data were collected by means of pClamp software via a Digidata 1200 interface (Axon Instruments) and a Gould chart recorder. Drugs and other agents were obtained from the following sources: tetrodotoxin (TTX) from Sigma and NMDA from Research Biochemicals (Natick, MA).
A

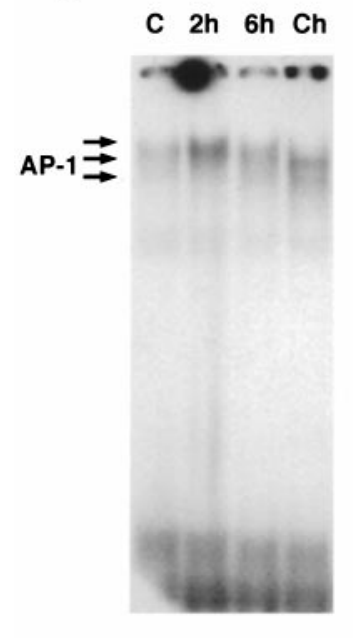

B

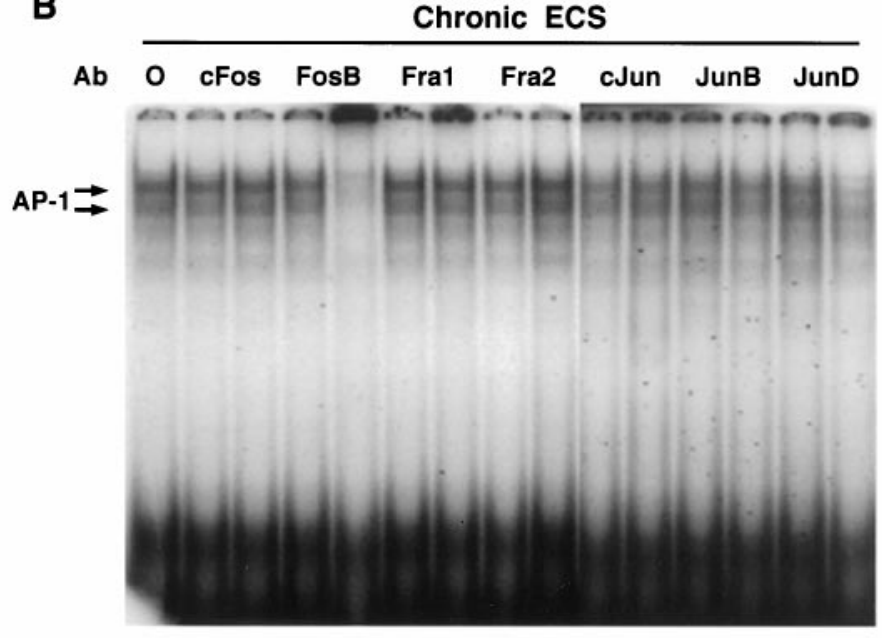

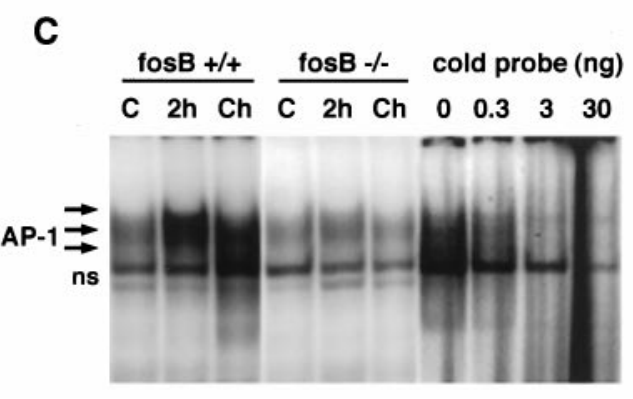

D

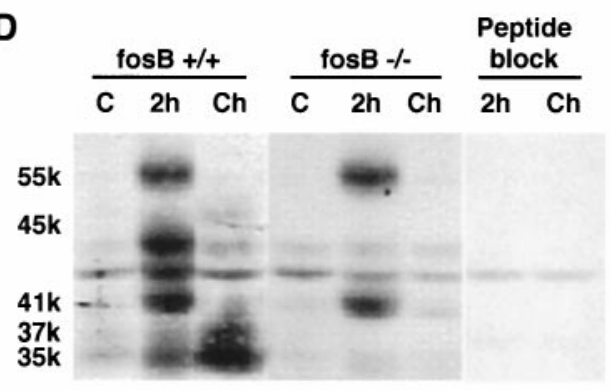

Figure 1. A, Induction of AP-1 binding by acute (2 or $6 \mathrm{hr}$ ) and chronic $(C h)$ ECS treatments in rat frontal cortex. Arrows on the left indicate specific AP-1 activity, determined by competition with nonradioactive probe (see also Hope et al., 1994b). $B$, Disruption of chronic AP-1 binding activity in rat frontal cortex by anti-Fos or anti-Jun family member antibodies $(A b)$. 0, No antibody added. Two dilutions $(l e f t, 1: 30 ;$ right, 1:3) of primary antiserum were used (see Materials and Methods). The figure is representative of results obtained from at least six samples in each group in at least three separate experiments. $C$, Induction of AP-1 binding by acute $(2 \mathrm{hr})$ and chronic ECS treatments in the frontal cortex of wild-type littermates $($ fos $\mathrm{B}+/+)$ and fos $\mathrm{B}$ mutant mice ( fos $\mathrm{B}-/-$ ). For treatments, see Materials and Methods. $C$, Sham-treated mice; $n s$, nonspecific bands. The four right lanes show competition of the specific AP-1 complex with nonradioactive AP-1 probe. The figure is representative of results obtained from analysis of at least nine samples in each group in at least three separate experiments. $D$, Induction of Fos-like proteins by acute and chronic ECS treatments in the frontal cortex of wild-type littermates $($ fos $\mathrm{B}+/+)$ and $f o s \mathrm{~B}$ mutant mice $(f o s \mathrm{~B}-/-)$. The figure is representative of results obtained from analysis of at least nine samples in each group in at least three separate experiments. The peptide block experiment verifies the specificity of the immunoreactive bands (see Materials and Methods). 
A

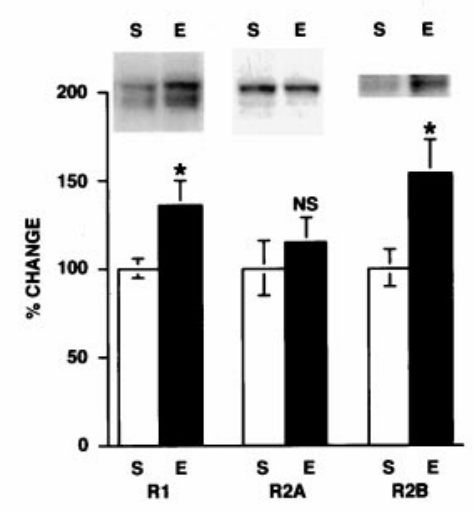

B

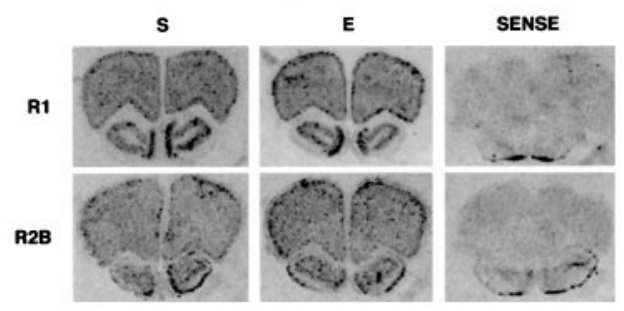

Figure 2. A, Effect of chronic ECS treatment on the levels of NMDA receptor subunit immunoreactivity in rat frontal cortex as determined by Western blotting. Data are expressed as mean \pm SEM. $S$, Sham $(n=7)$; $E$, chronic ECS $(n=9) ; R 1$, NMDAR1; $R 2 A$, NMDAR2A; $R 2 B$, NMDAR2B; *, statistically significant difference from controls; $N S$, no statistically significant difference from controls (Fisher LSD protected $t$ tests). $B$, Effect of chronic ECS treatment on levels of $R 1$ and $R 2 B$ mRNA in the rat frontal cortex as determined by in situ hybridization $(n=4$ for $S ; n=4$ for $E$ ). The right column (sense) shows the lack of signals with sense probes (see Materials and Methods).

Statistical analyses. Data obtained in this study, whether from Western blots, gel shift assays, immunohistochemistry, in situ hybridization, behavioral assays, or electrophysiological recordings, were first examined for their statistical significance by use of the ANOVA. Differences that were significant with this measure were further evaluated by use of Fisher LSD protected $t$ tests.

\section{RESULTS}

\section{Repeated ECS administration induces FosB/DFosB in frontal cortex}

We attempted to identify Fos and Jun family member transcription factors that are selectively induced in response to repeated administration of ECS. Although the chronic FRAs have been shown to be immunochemically related to $\triangle \mathrm{FosB}$, a truncated splice variant of FosB (Dobrazanski et al., 1991; Mumberg et al., 1991; Nakabeppu and Nathans, 1991; Yen et al., 1991), the identity of the proteins has remained controversial (Hope et al., 1994a; Chen et al., 1995; Bing et al., 1996, 1997) (see Discussion). This is because their apparent molecular weight on SDS-PAGE can be distinguished from $\triangle \mathrm{FosB}$ induced in brain by acute stimuli (Hope et al., 1994a; Chen et al., 1995) and because $\Delta$ fosB mRNA is not detectable at the time the chronic FRAs are induced (Chen et al., 1995; Bing et al., 1996, 1997). Indeed, these findings have led to speculation that the chronic FR As are products of a novel fos-related gene.

As a first step in identifying the constituents of the AP-1 complex induced by chronic ECS administration, we used antibodies selective for each of the known Fos and Jun family member proteins in supershift assays. The specificity and lack of cross-reactivity of these antibodies have been well characterized (Gruda et al., 1996). As shown in Figure $1 A$, chronic ECS resulted in an $\sim 70 \%$ increase in AP-1 binding activity in rat frontal cortex, as observed previously (Hope et al., 1994b). The specificity of the AP-1 complex has been well characterized using mutant AP-1 probe and AP-1 probe for competition (see Hope et al., 1994b). This chronic AP-1 complex was disrupted by an anti-FosB/ $\Delta$ FosB antibody, whereas antibodies directed against other Fos family members, c-Fos, FRA-1, or FRA-2, were without effect (Fig. 1B). The chronic AP-1 complex was also disrupted by an anti-JunD antibody, whereas an anti-c-Jun antibody was without effect. An anti-JunB antibody produced a small but consistent decrement in levels of AP-1 binding. These results indicate that the chronic AP-1 complex is composed predominantly of a FosB/ $\Delta$ FosB-like protein(s) coupled to JunD and, to a lesser extent, JunB.

To obtain further evidence that the chronic AP-1 complex required fos $\mathrm{B}$ gene products, we examined the ability of chronic ECS to induce AP-1 binding activity in fos B mutant mice. It was found that chronic ECS increased AP-1 binding activity in the frontal cortex of wild-type mice (Fig. 1C), similar to the increase seen in rat. In contrast, the ability of chronic ECS to induce AP-1 binding activity in this brain region was completely absent in fos $\mathrm{B}$ mutant mice.

To identify the specific FosB/ $\Delta$ FosB-like proteins that comprise the chronic AP-1 complex, we next analyzed extracts of frontal cortex from fosB mutant and wild-type mice by Western blotting, using an "anti-FRA" antibody that recognizes all known Fos-like proteins. As shown in Figure 1D, chronic ECS resulted in the induction of 35-37 kDa proteins (chronic FRAs) and a 45 $\mathrm{kDa}$ protein, equivalent to the effects seen in the rat (Hope et al., 1994b). In contrast, induction of the 35-37 kDa and $45 \mathrm{kDa}$ FR As was completely absent in the fos $\mathrm{B}$ mutant mice. There persisted in the mutant a low intensity band below $45 \mathrm{kDa}$, also seen in wild-type, which was not regulated by seizure treatment (Fig. $1 D$ ). Although the identity of this band remains unknown, it would seem to be a specific FRA given its ability to be competed by blocking peptide as shown in Figure $1 D$.

Also shown in Figure $1 D$ is the induction of Fos-like proteins in response to a single acute ECS. In wild-type mice, four major Fos-like proteins were induced: a $55 \mathrm{kDa}$ protein (presumably c-Fos), a $45 \mathrm{kDa}$ protein (presumably FosB), a $41 \mathrm{kDa}$ protein (presumably FRA-1 or FRA-2), and 35-37 kDa proteins (presumably $\Delta$ FosB). In the mutant mice, induction of the $45 \mathrm{kDa}$ and 35-37 kDa proteins was completely absent, consistent with the identification of these proteins as FosB and $\Delta \mathrm{FosB}$, respectively, whereas induction of the 55 and $41 \mathrm{kDa}$ proteins was normal, consistent with their identification as products of distinct genes. Indeed, these findings confirm that the targeted disruption of the $f o s \mathrm{~B}$ gene selectively blocked the production of fos $\mathrm{B}$ gene products without altering other Fos family member proteins.

The ability of a single ECS to acutely ( $2 \mathrm{hr}$ later) induce the various Fos-like proteins in wild-type and fos $\mathrm{B}$ mutant mice is consistent with results obtained with AP-1 binding (Fig. 1C). Thus, acute ECS increased AP-1 binding in frontal cortex of mutant mice (in contrast to the lack of induction by chronic ECS), although a lower level of induction was seen in mutant mice compared with wild-type littermates. This is consistent with the loss of induction of the 45 and $35-37 \mathrm{kDa}$ proteins but normal induction of the 55 and $41 \mathrm{kDa}$ proteins. Also evident in Figure $1, A$ and $C$, is the different migration pattern of the AP- 1 complex induced acutely versus chronically; the acute complex (in both 

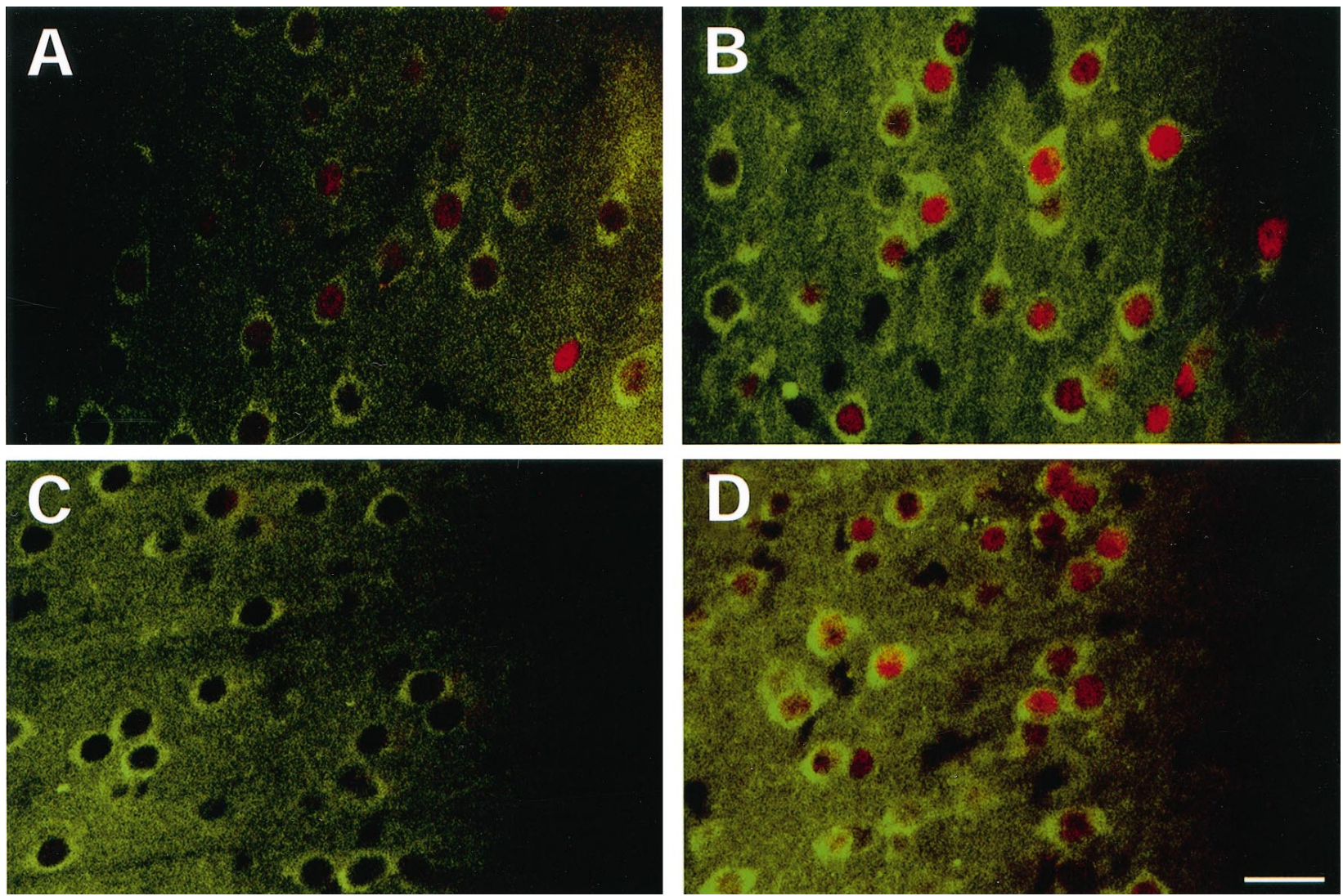

Figure 3. Colocalization of FRA and NMDAR1 immunoreactivity in rat motor cortex $(A, B)$ and medial prefrontal cortex $(C, D)$. $A, C, \operatorname{Sham}$ treatment; $B, D$, chronic ECS treatment. Rats received six daily ECS treatments and were used on day 7. Red staining represents FRA immunoreactivity; green staining represents NMDAR1 immunoreactivity. The left sides in $A$ and $B$ are medial to the right sides. The right sides in $C$ and $D$ are layer I. All the images were centered in layer II. Note the generally higher basal levels of FR A immunoreactivity in motor cortex $(A)$ than in prefrontal cortex $(C)$. The observation that some FRA-negative cells express NMDAR1 in both brain regions under basal conditions suggests that, although the AP-1 transcription factor seems to be important for ECS induction of NMDAR1 expression, it may not be required for basal expression of the subunit. Scale bar, $25 \mu \mathrm{m}$. The figure is representative of results obtained from analyses of four sham- and four ECS-treated rats.

rats and mice) migrates slightly higher on the gels compared with the migration of the chronic complex. This difference in migration is consistent with the different protein compositions of these two complexes.

The fos $\mathrm{B}$ gene produces two protein products through alternative splicing: full-length FosB $(45 \mathrm{kDa})$ plus $\Delta$ FosB $(\sim 35 \mathrm{kDa})$ that lacks the $\mathrm{C}$ terminal of the full-length form. By the use of antibodies directed against the $\mathrm{N}$ and $\mathrm{C}$ terminals of FosB, we found that the chronic FRAs are recognized by the N-terminal antibody only (data not shown). These results, along with the finding that all of the chronic FRA bands are absent in fos $\mathrm{B}$ mutant mice, indicate that the chronic FRAs and the $45 \mathrm{kDa}$ FRA are isoforms of $\Delta$ FosB and FosB, respectively.

\section{Repeated motor seizure regulates the expression of NMDA receptor subunits}

ECS treatment consistently induces a motor seizure, which is characterized by clonic jerking of major muscle groups of the body (McNamara, 1994). In contrast to limbic seizures, which occur via activation of excitatory pathways in limbic brain structures (e.g., hippocampus and amygdala), motor seizures depend on activation of NMDA glutamate receptors in the motor cortex (Clineschmidt et al., 1982; Nomikos et al., 1992; McNamara, 1994). NMDA receptors are multimeric proteins composed of several subunits. The NMDAR1 subunit is an obligatory constituent of functional NMDA receptors; this subunit can form com- plexes with any of several NMDAR2 subunits. NMDA receptors composed of different combinations of subunits exhibit distinct electrophysiological properties (Monyer et al., 1992; Nakanishi, 1992) and distinct developmental courses (Sheng et al., 1994).

Given the obligatory role of the NMDA receptor in the production of motor seizures, we asked whether repeated ECS might alter NMDA receptor subunit expression. The rodent cerebral cortex contains NMDAR1 and two forms of NMDAR2, NMDAR2A and NMDAR2B; two other known forms of NMDAR2, NMDAR2C or NMDAR2D, are not abundantly expressed in this brain region (Monyer et al., 1992; Nakanishi, 1992; Ishii et al., 1993). Thus, we examined regulation of NMDAR1, NMDAR2A, and NMDAR2B by ECS. As shown in Figure $2 A$, chronic ECS (with animals examined 18-20 hr after the last ECS) significantly increased levels of immunoreactivity of NMDAR1 $[t(14)=2.03 ; p<0.05]$ and NMDAR2B $[t(9)=2.53$; $p<0.05]$ in rat frontal cortex as determined by Western blotting. No change was seen in levels of NMDAR2A immunoreactivity $[t(14)=0.83 ; p>0.05]$. In contrast to chronic ECS, a single ECS treatment (with animals examined 18-20 hr later) decreased levels of NMDAR1 [29\%; $t(14)=2.43 ; p<0.05$ ], increased levels of NMDAR2B [70\%; $t(15)=2.57 ; p<0.05]$, and had no effect on levels of NMDAR2A $[t(15)=0.91 ; p>0.05]$.

To gain greater insight into the anatomical localization of ECS-induced upregulation of NMDA receptor subunit expres- 
A

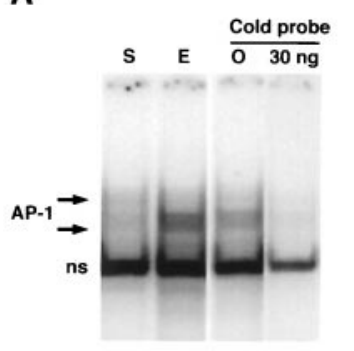

C

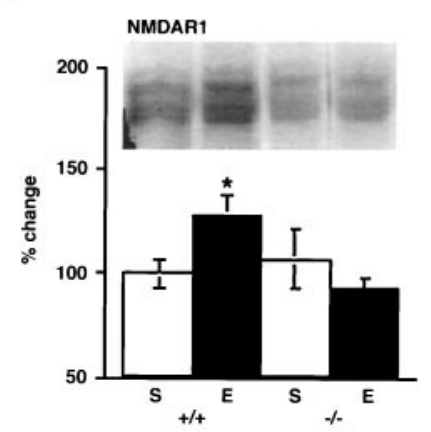

B
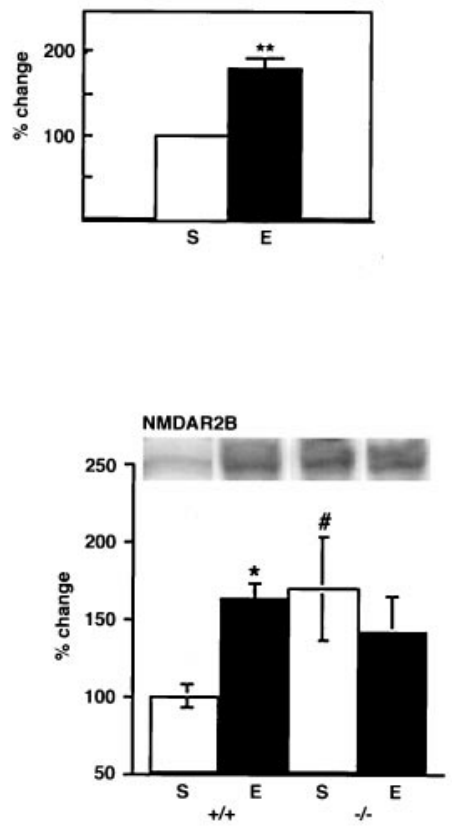

Figure 4. A, Induction of AP-1 binding by chronic ECS treatment in rat frontal cortex using a radioactively labeled probe corresponding to the AP-1 site in the NMDAR1 gene promoter. Specificity of the AP-1 binding was established by competition with nonradioactive probe (30 ng). S, Sham; $E$, chronic ECS. $B$, Quantification of AP-1 binding activity shown in $A$. The entire AP-1 complex indicated by arrows in $A$ was measured. Data are expressed as mean $\pm \operatorname{SEM}(n=8$ for $S ; n=10$ for $E) . * *$, Statistically significant difference from control $(p<0.01)(t$ test $)$. $C$, Effect of chronic ECS treatment on levels of NMDAR1 and NMDAR2B immunoreactivity in frontal cortex of wild-type littermates $(+/+; n=6$ for $S ; n=13$ for $E)$ and fos B mutant mice $(-/-; n=5$ for $S ; n=8$ for $E)$. *, Statistically significant difference between $S+/+$ and $E+/+(p<0.05)$; \#, statistically significant difference between $S+/+$ and $S-/-$ (Fisher LSD protected $t$ tests).

sion, we studied levels of NMDAR1 and NMDAR2B mRNAs in the rat frontal cortex by in situ hybridization. This analysis revealed that upregulation of NMDAR1 mRNA levels occurs most strikingly in superficial layers of the frontal cortex $[t(100)=2.62$; $p<0.05]$ but not in deep layers $[t(100)=0.57 ; p>0.05]$ (Fig. $2 B$ ). Similarly, upregulation of NMDAR2B mRNA levels was significant in superficial layers $[t(93)=2.21 ; p<0.05]$ but not in deep layers $[t(74)=0.52 ; p>0.05]$. For both $\mathrm{R} 1$ and $\mathrm{R} 2 \mathrm{~B}$, upregulated mRNAs were most apparent in the superficial (II and III) layers of the dorsal and lateral cortices (see a band-like pattern).

\section{NMDAR1 is a putative physiological target of the chronic AP-1 complex}

Given that the observed induction of NMDAR1 and of the chronic AP-1 complex required chronic (as opposed to acute) ECS administration, we considered the possibility that the gene encoding this receptor subunit may be a physiological target for the chronic AP-1 complex composed predominantly of $\Delta \mathrm{FosB}$ and JunD. Support for this possibility is the finding that the 5 '-promoter of the NMDAR1 gene contains a consensus AP-1 site (Bai and Kusiak, 1993).

As a first step in assessing the role of $\Delta$ FosB in regulating NMDAR1 gene expression, we determined whether induction of the proteins occurs in the same cells by use of double-labeling immunofluorescence. This experiment revealed that chronic ECS

produced a dramatic (fourfold) increase in Fos-like immunoreactivity in layers II and III throughout the rat frontal cortex (sham, $30 \pm 3$ FRA-positive nuclei per $0.3 \mathrm{~mm}^{2}$ area \pm SEM; ECS, $127 \pm 6 ; p<0.01$; based on analysis of 21 samples derived from four rats in each group), with no increase observed in deep cortical layers (sham, $10 \pm 2$; ECS, $12 \pm 2 ; p>0.05$ ). A similar pattern was seen for NMDAR1-like immunoreactivity, which showed the most dramatic increase in superficial cortical layers (data not shown). This is similar to the pattern of elevated levels of NMDAR1 and NMDAR2B mRNAs seen by in situ hybridization (see Fig. 2B). Moreover, increased levels of Fos-like proteins were found in neurons with upregulated NMDAR1-like immunoreactivity (Fig. 3). NMDAR1 immunoreactivity showed clear cytoplasmic and membrane staining, whereas Fos-like immunoreactivity showed nuclear localization, consistent with the known subcellular distribution of these proteins (Morgan and Curran, 1991a; Ehlers et al., 1995). Although this experiment was performed with the anti-FRA antibody, the large majority of the Fos-like immunoreactivity detected after chronic ECS probably represents $\Delta$ FosB isoforms (and to a lesser extent FosB) based on the preponderance of these proteins as revealed by Western blotting (Fig. 1D). Indeed, equivalent results were obtained by use of a selective anti-FosB/ $\Delta$ FosB antibody (data not shown). Nevertheless, some caution is needed when ascribing immunohistochemical staining to a particular protein.

We next determined whether the consensus AP-1 site present within the NMDAR1 gene promoter can bind the AP-1 complex induced by chronic ECS. Using a double-stranded oligonucleotide that corresponds to this region of the NMDAR1 promoter, we found that repeated ECS administration resulted in a clear increase in binding activity to this AP-1 site in extracts of rat frontal cortex $[t(16)=5.94 ; p<0.01]$ (Fig. $4 A, B)$. The specificity of this binding is demonstrated by its competition by unlabeled probe, shown in Figure $4 A$.

To study directly a role for $\triangle$ FosB in mediating the ECSinduced increase in NMDAR1 expression, we compared the ability of chronic ECS to upregulate levels of NMDAR1 immunoreactivity in frontal cortex of wild-type and fos B mutant mice. As shown in Figure $4 C$, chronic ECS increased levels of NMDAR1 immunoreactivity in the frontal cortex of wild-type mice $[t(29)=2.02 ; p<0.05]$, similar to the effect seen in rat (see Fig. $2 A$ ). In contrast, chronic ECS failed to alter levels of the receptor subunit in this brain region of mutant mice. The basal levels of NMDAR1 did not differ between the mutant and wildtype mice $[t(24)=0.72 ; p>0.05]$. Moreover, induction of NMDAR1 and of FosB/AFosB-like immunoreactivity showed similar colocalization in the cortex of wild-type mice (data not shown) as seen in the rat (Fig. 3). As would be expected, there was no detectable FosB $/ \Delta$ FosB-like immunoreactivity in fos $\mathrm{B}$ mutant mice (data not shown). Together, these results provide direct evidence that the NMDAR1 gene is indeed a potential physiological target for fos $\mathrm{B}$ gene products in the brain in vivo.

Because the 5'-region of the NMDAR2B gene cloned to date also contains an AP-1-like site (Sasner and Buonanno, 1996), we were interested in determining whether ECS regulation of this subunit was similarly aberrant in the mutant mice. Indeed, chronic ECS did not alter levels of NMDAR2B immunoreactivity in the fos B mutant mice $[t(24)=0.72 ; p>0.05]$ in contrast to the increase seen in wild-type littermates $[t(43)=2.01 ; p<0.05]$ (Fig. 4C). However, basal levels of NMDAR2B immunoreactivity were significantly higher in the mutant mice than in wild-type littermates $[t(24)=2.87 ; p<0.01]$. It remains unclear, therefore, 
Figure 5. Left, Effect of chronic ECS treatment on the duration of motor seizures in rats $(n=9)$. *, Statistically significant difference from day 1 (Fisher LSD protected $t$ tests). Right, Effect of chronic ECS treatment on the duration of motor seizures in fos $\mathrm{B}$ mutant mice $(n=21)$ and their wild-type littermates $(n=13)$. Data are expressed as mean \pm SEM; *, statistically significant difference from day 1 ; \#, statistically significant difference between fos B mutant mice and their wild-type littermates (Fisher LSD protected $t$ tests).
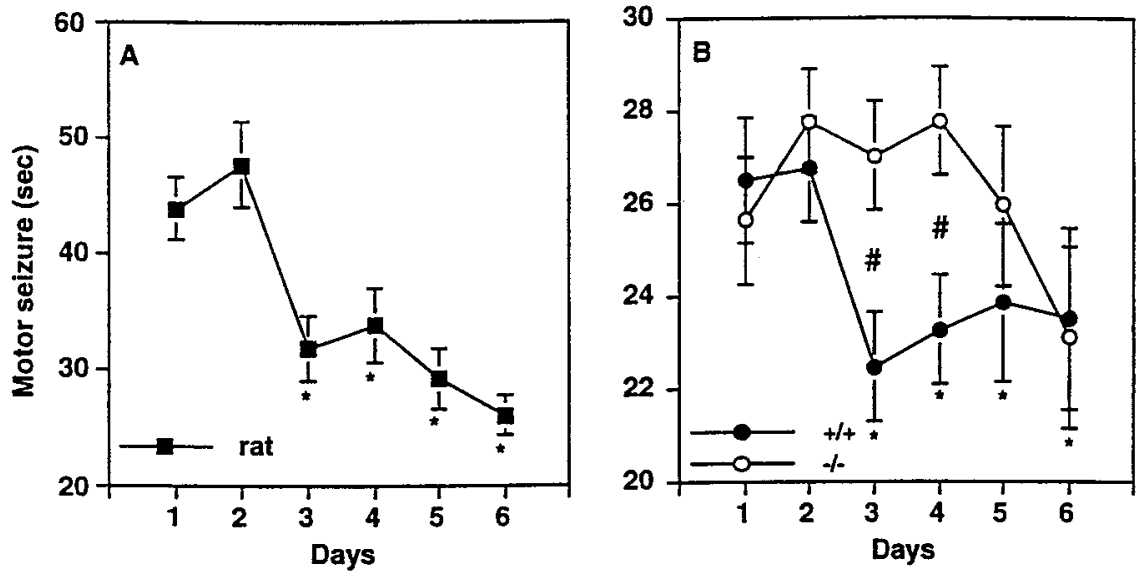

how $\Delta$ FosB and FosB serve to regulate NMDAR2B gene expression under both basal and stimulated conditions.

\section{fosB gene products are required for behavioral tolerance to repeated ECS}

We next studied whether induction of FosB $/ \Delta$ FosB could be correlated with some form of behavioral plasticity to ECS treatment. As shown in Figure 5, left, we found that repeated administration of ECS induced a progressively shorter motor seizure in rats, an effect that was near maximal by day 3. This form of tolerance has not been recognized previously but is consistent with the clear tolerance that develops in humans undergoing chronic treatment with ECS (Fink, 1990).

A similar reduction in the duration of motor seizures was observed in wild-type mice (Fig. 5, right). The reduction occurred with a time course equivalent to that seen in rats but was smaller in magnitude $(\sim 17 \%)$. In contrast to wild-type mice, fos $\mathrm{B}$ mutant mice showed a significant delay in the development of tolerance to motor seizures, even though the motor seizure induced in the mutant mice by the first ECS was indistinguishable from that exhibited by wild-type littermates $[t(32)=0.59 ; p>0.05]$. Continued treatment with ECS, however, did eventually result in a significant reduction in seizure duration, with equivalent motor seizures observed in mutant and wild-type mice by day 6 .

\section{fosB gene products are required for electrophysiological adaptation to repeated ECS}

Given alterations in NMDA receptor subunit expression and in duration of motor seizures after repeated ECS, we next studied electrophysiological responses of layer II/III pyramidal cells to NMDA in the motor cortex of wild-type and fos B mutant mice. Recordings were made from cells that showed characteristics of regularly spiking pyramidal cells (Fig. 6A) (McCormick et al., 1985; Connors and Gutnick, 1990). In sham-treated wild-type mice, we found that increasing concentrations of NMDA (from 6.25 to $25 \mu \mathrm{M}$ ) induced increasing inward currents that reached $\sim 90 \mathrm{pA}$ at $25 \mu \mathrm{M}$ NMDA (Fig. $6 B, C$ ). Consistent with previous findings in rat cerebral cortex, NMDA concentrations of $50 \mu \mathrm{M}$ or greater, bath applied for 1-2 min periods, induced very large (4-5 $\mathrm{nA}$ ) inward currents in cells from wild-type mice (data not shown), currents that far exceed the physiological range and are associated with excitotoxicity. Thus, we did not regularly test 50 $\mu \mathrm{M}$ NMDA in wild-type mice and typically used a $25 \mu \mathrm{M}$ NMDA concentration.

In these experiments, mice were studied $24 \mathrm{hr}$ after the second of two daily ECS, because it was at this time point that maximal differences in seizure duration were observed between wild-type and mutant mice (see Fig. 5, right). Such repeated treatment with ECS decreased the NMDA-induced inward current $24 \mathrm{hr}$ after the last ECS treatment in wild-type mice [69\%; $t(11)=3.36 ; p<$ 0.01] (Fig. 6D,E). In contrast, repeated ECS treatment did not alter the $25 \mu \mathrm{M}$ NMDA-induced inward currents in cells from mutant mice $[t(13)=1.13 ; p>0.05]$, although the baseline currents were lower in sham-treated mutant mice than in shamtreated wild-type mice [78\% decrease; $t(13)=4.53 ; p<0.001$ ]. However, the failure of cells from mutant mice to show an adaptation to repeated ECS did not represent a "floor" effect, because a higher concentration of NMDA $(50 \mu \mathrm{M})$, which elicited larger currents-but still ones in the physiological range-in the mutants, also revealed a lack of adaptation to repeated ECS in the mutant mice $[t(10)=0.53 ; p<0.05]$ (Fig. $6 E$ ). The NMDAinduced inward currents seemed to be caused by the postsynaptic action of NMDA on the pyramidal cells, because the fast sodium channel blocker TTX did not alter the NMDA responses in six cells from both ECS- and sham-treated mice $[t(5)=0.34 ; p>$ 0.05] (Fig. 6F).

\section{fos B mutant mice have normal cytoarchitecture in the frontal cortex}

Targeted disruption of a gene can cause severe anatomical abnormalities attributable to developmental effects of the disruption, which could lead to significant phenotypic abnormalities in the adult animals (e.g., Xu et al., 1994). This is a particular concern in the present study, because FosB/ $\Delta$ FosB-like proteins are expressed during cortical development (Kaminska et al., 1995). Thus, we examined the cytoarchitecture of superficial layers of the frontal cortex of fos $\mathrm{B}$ mutant mice to assess the anatomical integrity of this brain region. We first examined the calcium-binding protein calbindin that is expressed in GABAergic, nonpyramidal neurons and in pyramidal neurons within cerebral cortex (Kubota et al., 1994; Gabbott et al., 1997; Kawaguchi and Kubota, 1997). Calbindin is particularly enriched in superficial cortical layers, where it can be used immunohistochemically to stain both cell bodies and a dense fiber network (Celio, 1990; van Brederode et al., 1991). As shown in Figure 7, calbindin immunoreactivity showed a normal distribution in the motor and medial prefrontal cortex of mutant mice. The dorsomedial corner of the frontal cortex showed lower levels of calbindin-positive cell bodies and fibers in wild-type and mutant mice, although there was considerable individual variation in the size of this calbindinpoor area in both types of mice. We also examined NMDAR1, 
A

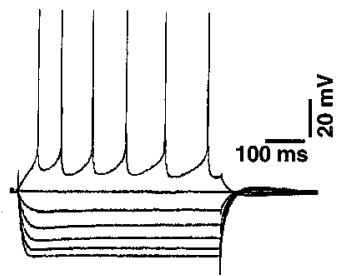

C

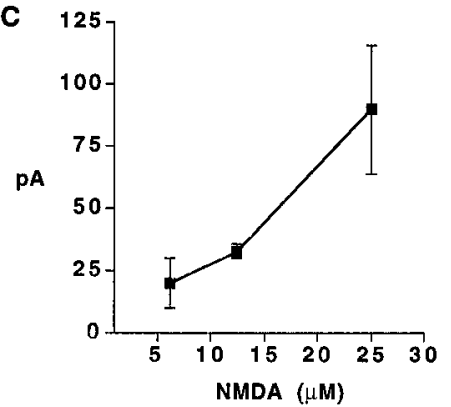

E

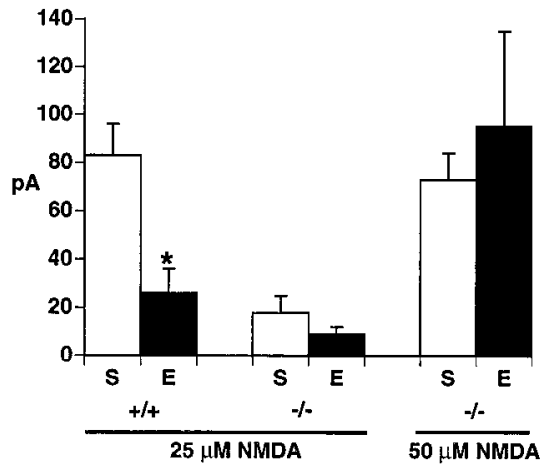

B $\mathrm{s}+1+$

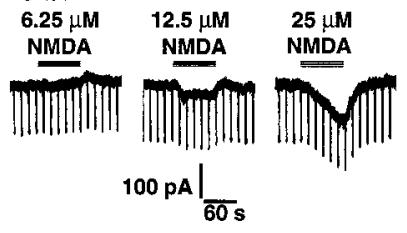

D
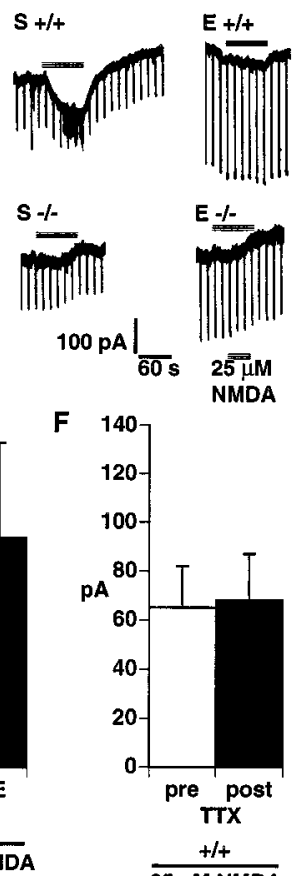

Figure 6. NMDA-induced inward currents in pyramidal cells in the motor cortex. $A$, Responses of a layer II/III pyramidal cell of the motor cortex to an incremental series of current pulses ( $-0.2 \mathrm{nA}$ steps). An intracellular recording with a $\mathrm{K}$ acetate electrode is shown. $B$, In voltageclamp mode at a holding potential of $-55 \mathrm{mV}$, current traces from a layer II/III pyramidal cell of a sham-treated, wild-type $(+/+)$ mouse in response to a $1.5 \mathrm{~min}$ bath application of $6.25,12.5$, and $25 \mu \mathrm{M}$ NMDA separated by at least $10 \mathrm{~min}$. This same cell responded to $50 \mu \mathrm{M}$ NMDA with a $4.5 \mathrm{nA}$ inward current (data not shown). $C$, NMDA-induced inward currents (at NMDA concentrations of 6.25, 12.5, and $25 \mu \mathrm{M}$ ) in sham-treated, wild-type mice $(n=3)$. D, Current traces at a holding potential of $-55 \mathrm{mV}$ from layer II/III pyramidal cells from wild-type $(+/+)$ or fos B mutant $(-/-)$ mice in response to a 1.5 min bath application of $25 \mu \mathrm{M}$ NMDA. $S$, Sham; $E$, two daily ECS treatments (animals were killed $24 \mathrm{hr}$ later). $E$, A summary of the results of experiments measuring the NMDA-induced inward current $(+/+; n=7$ for $S ; n=6$ for $E ;-/-, n=8$ for $S ; n=6$ for $E$ ). *, Statistically significant difference between sham- and ECS-treated groups (Fisher LSD protected $t$ tests). $F$, A summary of experiments in six separate slices $(+/+, n=4$ for $S ; n=$ 2 for $E)$ in which the NMDA $(25 \mu \mathrm{M})$-induced inward currents were measured both before and after bath application of tetrodotoxin (TTX;2 $\mu \mathrm{M})$, which completely blocked the spiking activity of each cell tested.

which is highly expressed in cortical pyramidal and other neurons (see Monyer et al., 1992; Nakanishi, 1992). Again, superficial layers showed apparently normal patterns of NMDAR1immunoreactive neurons in the motor area of the prefrontal cortex of mutant mice (Fig. 7). This is consistent with equivalent levels of NMDAR1 in the frontal cortex of sham-treated wildtype and mutant mice as determined by Western blotting (see Fig. $4 C$ ). Finally, Nissl staining revealed apparently normal organization of cells in these brain regions (Fig. 7). Although these analyses do not eliminate the possibility of a subtle abnormality, they demonstrate that the various biochemical, behavioral, and electrophysiological phenotypes in the fos $\mathrm{B}$ mutant mice are not associated with a gross abnormality in the cytoarchitecture of the superficial layers of cortex in these animals.

\section{DISCUSSION}

We showed in the present study, by use of a mutant mouse that lacks the fos B gene, that the $45 \mathrm{kDa}$ FRA and the chronic FRAs induced by repeated ECS were FosB and novel isoforms of $\Delta$ FosB, respectively, and that they complexed predominantly with JunD/JunB to form the chronic AP-1 complex. We provided several lines of evidence that a specific NMDA receptor subunit, which was upregulated by chronic ECS, was a physiological target gene for this chronic AP-1 complex. Altered expression of NMDA receptor subunits was associated with altered electrophysiological responses of cortical pyramidal neurons to NMDA, an effect that was lost in fos B mutant mice. Moreover, tolerance developed to the production of motor seizures in rats and mice, and the development of this tolerance was delayed in fos B mutant mice.

\section{Chronic FRAs are isoforms of $\triangle F$ FosB}

The present study provides strong evidence that all of the chronic FRAs induced by repeated motor seizures are encoded in the fos $\mathrm{B}$ gene. Together with our previous finding that $\Delta$ FosB overexpressed in cell lines migrates at 35-37 kDa (J. S. Chen et al., 1997), the present result establishes the 35-37 kDa FRAs induced in the cortex by repeated motor seizures as isoforms of $\Delta$ FosB. FosB mutant mice also exhibit lack of induction of the chronic FRAs in striatum in response to chronic cocaine administration (Hiroi et al., 1997) and in hippocampus after kainate lesions (Mandelzys et al., 1997). Although it has remained unclear whether chronic FRAs induced by various chemical and electrical treatments are identical, these observations indicate that diverse types of chemical and electrical stimulation induce common transcription factors, $\Delta$ FosB isoforms, and, to a lesser extent, FosB in a region-specific manner in brain.

\section{fosB gene products are required for seizure- associated reorganization of NMDA receptors}

The present study provides several lines of evidence that the NMDAR1 gene is a physiological target for fos $\mathrm{B}$ gene products, presumably $\Delta$ FosB. First, repeated ECS administration upregulated levels of NMDAR1, an obligatory subunit of NMDA receptors, in the frontal cortex of rats and wild-type mice, an effect that was completely absent in fos B mutant mice. Second, upregulation of NMDAR1 and induction of $\Delta$ FosB/FosB-like proteins were colocalized to the same subpopulations of neurons in the frontal cortex. Third, repeated ECS treatment increased AP-1 binding activity at the AP-1 site encoded in the promoter of the NMDAR1 gene. Fourth, the NMDAR1 subunit was upregulated at the mRNA level, consistent with the notion that regulation of gene transcription is involved. Fifth, the absence of fos $\mathrm{B}$ gene products alone was sufficient for the defective upregulation of NMDAR1; other Fos family proteins were induced by a single ECS equally in both the mutant and wild-type mice. These findings suggest that $\Delta$ FosB isoforms (and perhaps FosB), rather than other Fos family member proteins, are responsible for the upregulation of NMDAR1 by repeated ECS treatment. It should be pointed out, however, that we do not eliminate the possibility that fos $\mathrm{B}$ gene products act on other genes to bring about the upregulation of the NMDAR1 gene. 


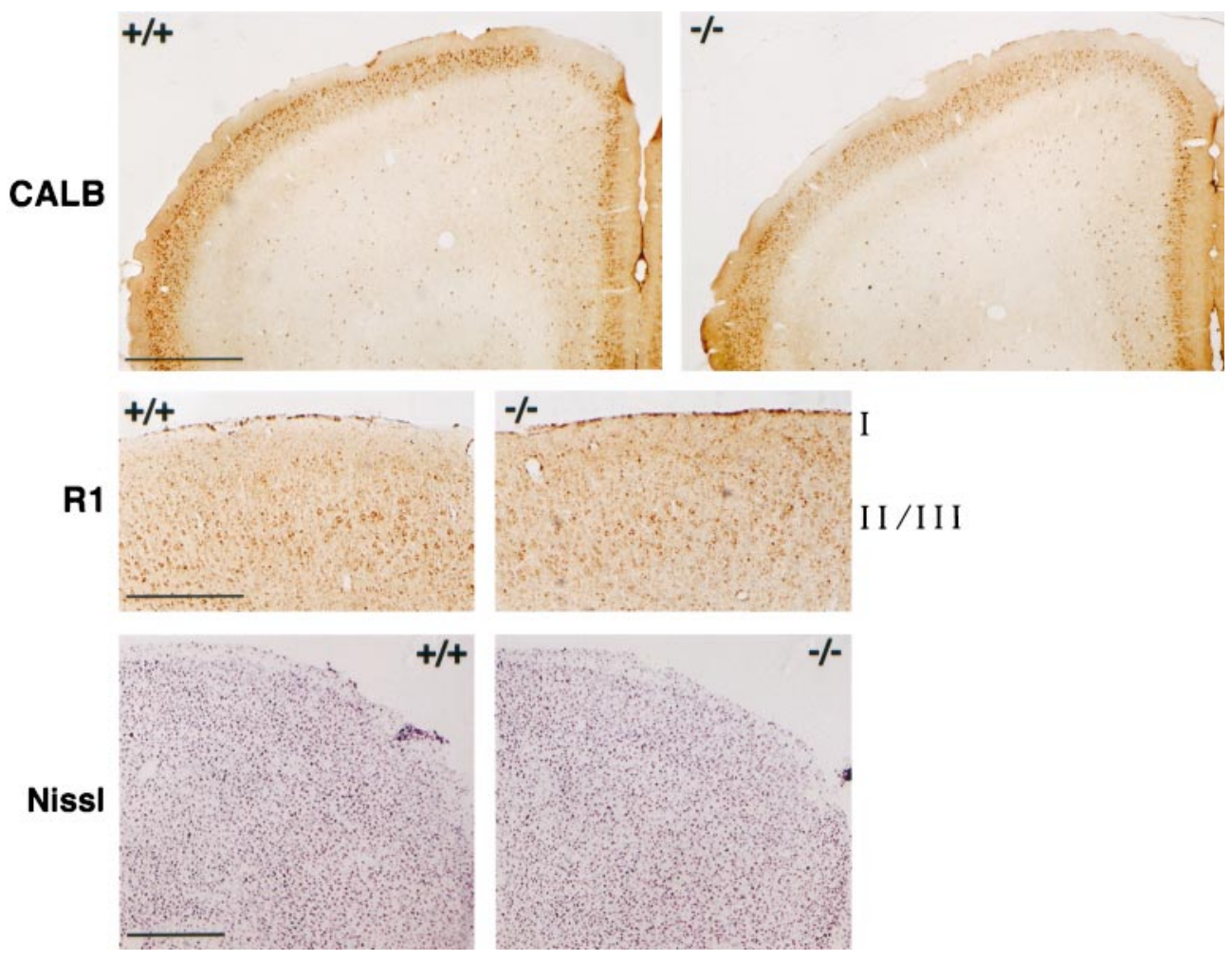

Figure 7. Cytoarchitecture of the frontal cortex. Immunoreactivity of calbindin (CALB) (top), immunoreactivity of NMDAR1 (R1) (middle; showing the motor cortex), and Nissl staining (bottom; showing the dorsolateral quadrant of the frontal cortex) are shown. Scale bars: top, bottom, $500 \mu$ m; middle, $250 \mu \mathrm{m}$. The figure is representative of results obtained from analysis of four wild-type littermates $(+/+)$ and four fos B mutant mice $(-/-)$.

\section{fosB gene products are required for the normal development of tolerance to motor seizures}

The present study also demonstrates that tolerance develops with respect to the duration of the motor seizure elicited by repeated ECS administration in rodents. Such tolerance to ECS has been widely noted in clinical practice during the use of repeated ECS for the treatment of affective disorders such as depression (Fink, 1990). Although this tolerance can complicate the clinical use of ECS (Fink, 1994), it also could reflect neural adaptations related to its therapeutic efficacy. Our results establish that this tolerance in part depends on transcriptional regulation by fos $\mathrm{B}$ gene products. The results also indicate that the acute induction of motor seizure by a single ECS does not require the protein products of the fos $\mathrm{B}$ gene but that its behavioral adaptation does.

It should be noted that tolerance to the duration of motor seizure was not completely abolished in fos B mutant mice, because tolerance, equivalent to that seen in wild-type mice, eventually developed after a larger number of ECS treatments. This observation raises the possibility that, in the absence of fos $\mathrm{B}$ gene products, other factors eventually substitute (see Hummler et al., 1994). It is unlikely, however, that other Fos family member proteins played a compensatory role, because no upregulation was seen in these proteins (see Fig. 1D). Alternatively, only an initial phase of tolerance might require fos $\mathrm{B}$ gene products. With respect to this possibility, it is interesting to note that such a phase-specific involvement of a transcription factor (e.g., cAMP response element binding protein) has been demonstrated in Drosophila (DeZazzo and Tully, 1995), Aplysia (Bailey et al., 1996), and mice (Bailey et al., 1996). If this were the case here, tolerance to motor seizure would involve more than one neuroadaptive process with distinct temporal properties. According to this scheme, transcriptional regulation by fos $\mathrm{B}$ gene products would be the basis of the rapid, initial reduction in seizure duration.

The tolerance elicited by repeated administration of ECS is qualitatively different from the consequences of repeated limbic seizures. Repeated subthreshold stimulation of limbic structures (e.g., amygdala and perforant path) leads to a gradual reduction in seizure threshold and eventually to intense limbic seizures (i.e., kindling) (McNamara, 1994). Given that kainate-induced seizures are associated with induction of the 35-37 kDa FRAs (Sonnenberg et al., 1989; Morgan and Curran, 1991b; Pennypacker et al., 1994), which are $\Delta$ FosB isoforms (Mandelzys et al., 1997), it would be interesting to study NMDA receptor subunits and other potential target genes for $\Delta$ FosB within the context of limbic seizures (see Friedman et al., 1994).

\section{fosB gene products are required for chronic ECS- induced desensitization of NMDA responses}

One major finding of the electrophysiological studies is that repeated ECS result in desensitization of NMDA-induced inward currents in neocortical layer II/III pyramidal cells of wildtype mice at the time when behavioral tolerance developed. This reduction in NMDA-induced inward currents is attenuated in fos $\mathrm{B}$ mutant mice. This suggests that fos $\mathrm{B}$ gene products are essential for the electrophysiological adaptation to reduce excessive glutamatergic transmission during motor seizures.

Paradoxically, the higher basal levels of the NMDAR2B subunit in fos B mutant mice were associated with electrophysiologically less effective NMDA receptors. By itself, a change in the ratio of NMDAR2A versus NMDAR2B subunits combined with the NMDAR1 subunits would not be expected to alter NMDA 
responses, because the conductance and mean open time for heteromeric expression of NMDAR1/NMDAR2A and NMDAR1/ NMDAR2B combinations is similar (Stern et al., 1992). Rather, the NMDAR2B subunit, coexpressed with the NMDAR1 subunit, is more sensitive to NMDA, glycine, and serine than is the NMDA2A subunit (Hess et al., 1996) and is less sensitive to $\mathrm{Mg}^{2+}$ block and inhibition by $\mathrm{Zn}^{2+}$ (Stern et al., 1992; N. Chen et al., 1997). Nevertheless, upregulation of NMDAR2B in the absence of a change in NMDAR2A could cause reduced inward currents to NMDA by producing greater basal desensitization in the presence of a given ambient glutamate concentration. This could explain the reduced basal responsiveness to NMDA, as well as the lack of adaptation in NMDA responsiveness after repeated ECS treatment, in fos B mutant mice. Such a paradox between an increased number of receptors and development of tolerance has been noted for another ionotropic receptor, the nicotinic cholinergic receptor, after chronic nicotine treatment (Marks et al., 1993).

Another important dissociation we observed is that constitutively higher levels of NMDAR2B (see Fig. 4C) and initially smaller NMDA-evoked inward currents (Fig. 6B,C) in mutant mice were not paralleled by a change in the duration of motor seizure by the initial ECS: a single, acute ECS induced the same duration of motor seizure in wild-type and mutant mice (see Fig. 5 , right, day 1). One possibility is that NMDAR2B alone may not be sufficient for setting the duration of motor seizure but may be sufficient for reducing NMDA-induced inward currents.

It should be pointed out that the present study was not designed to establish causal links among the neuronal (NMDAR1 upregulation), electrophysiological (inward current change), and behavioral (tolerance to motor seizures) phenotypes.

\section{Role for $\Delta$ FosB as a mediator of neural and behavioral plasticity}

The chronic FRAs have been shown to accumulate in a regionspecific manner in brain in response to several treatments, including chronic seizures, chronic psychotropic drug treatments, and kainate and other lesions (Hope et al., 1994a,b; Nye et al., 1995; Pennypacker et al., 1995; Doucet et al., 1996; Hiroi and Graybiel, 1996; Moratalla et al., 1996; Nye and Nestler, 1996; Mandelzys et al., 1997; Pich et al., 1997). Thus, accumulation of the chronic FRAs may be a common response of the brain to chronic perturbation (Hiroi et al., 1996). By establishing the identity of these proteins as novel $\Delta$ FosB isoforms, the results of the present study contribute to understanding the general role these transcription factors play in mediating long-term adaptations in the brain. By identifying a particular NMDA receptor subunit as a putative target gene for these transcription factors, the present study provides a model system to study the roles of fos $\mathrm{B}$ gene products and NMDA receptor regulation in many forms of neural and behavioral plasticity known to involve NMDA receptor activation.

\section{REFERENCES}

Aghajanian GK, Rasmussen K (1989) Intracellular studies in the facial nucleus illustrating a simple new method for obtaining viable motoneurons in adult rat brain slices. Synapse 3:331-338.

Bai G, Kusiak JW (1993) Cloning and analysis of the $5^{\prime}$ flanking sequence of the rat $N$-methyl-D-aspartate receptor 1 (NMDAR1) gene. Biochim Biophys Acta 1152:197-200.

Bailey CH, Bartsch D, Kandel ER (1996) Toward a molecular definition of long-term memory storage. Proc Natl Acad Sci USA 93:13445-13452.

Berhow MT, Hiroi N, Kobierski LA, Hyman SE, Nestler EJ (1996)
Influence of cocaine on the JAK-STAT pathway in the mesolimbic dopamine system. J Neurosci 16:8019-8026.

Bing G, McMillian M, Kim H, Pennypacker K, Feng Z, Qi Q, Kong L-Y, Iadarola M, Hong JS (1996) Long-term expression of the 35,000 mol. wt Fos-related antigen in rat brain after kainic acid treatment. Neuroscience 73:1159-1174.

Bing G, Wang W, Qi Q, Feng Z, Hudson P, Jin L, Zhang W, Bing R, Hong J-S (1997) Long-term expression of Fos-related antigen and transient expression of $\Delta$ FosB associated with seizures in the rat hippocampus and striatum. J Neurochem 68:272-279.

Brose N, Huntley GW, Stern-Bach Y, Sharma G, Morrison JH, Heinemann SF (1994) Differential assembly of coexpressed glutamate receptor subunits in neurons of rat cerebral cortex. J Biol Chem 269:16780-16784.

Brown JR, Ye H, Bronson RT, Dikkes P, Greenberg ME (1996) A defect in nurturing in mice lacking the immediate early gene fos $\mathrm{B}$. Cell 86:297-309.

Celio MR (1990) Calbindin D-28k and parvalbumin in the rat nervous system. Neuroscience 35:375-475 .

Chen JS, Nye HE, Kelz MB, Hiroi N, Nakabeppu Y, Hope BT, Nestler EJ (1995) Regulation of $\Delta$ FosB and FosB-like proteins by electroconvulsive seizure and cocaine treatment. Mol Pharmacol 48:880-889.

Chen JS, Kelz M, Hope BT, Nakabeppu Y, Nestler EJ (1997) Chronic Fos-related antigens: stable variants of $\Delta$ FosB induced in brain by chronic treatments. J Neurosci 17:4933-4941.

Chen N, Moshaver A, Raymond LA (1997) Differential sensitivity of recombinant $N$-methyl-D-aspartate receptor subtypes to zinc inhibition. Mol Pharmacol 51:1015-1023.

Clineschmidt B, Martin GE, Bunting PR (1982) Anticonvulsant activity of (+)-5-methyl-10,11-dihydro-5H-dibenzo[a,d]cylcohepten-5,10-imine (MK-801). A substance with potent anticonvulsant, central sympathomimetic, and apparent anxiolytic properties. Drug Dev Res 2:123-134.

Connors BW, Gutnick MJ (1990) Intrinsic firing patterns of diverse neocortical neurons. Trends Neurosci 13:99-104.

Devanand DP, Dwork AJ, Hutchison ER, Bowlig TG, Sackeim HA (1994) Does ECT alter brain structure? Am J Psychiatry 151:957-970.

DeZazzo J, Tully T (1995) Dissociation of memory formation: from behavioral pharmacology to molecular genetics. Trends Neurosci 18:212-218.

Dobrazanski P, Noguchi T, Kovary K, Rizzo CA, Lazo PS, Bravo R (1991) Both products of the fosB gene, FosB and its short form, FosB/SF, are transcriptional activators in fibroblasts. Mol Cell Biol 11:5470-5478.

Doucet JP, Nakabeppu Y, Bedard PJ, Hope BT, Nestler EJ, Jasmin BJ, Chen JS, Iadarola MJ, St-Jean M, Wigle N, Blanchet P, Grondin R, Robertson GS (1996) Chronic alterations in dopaminergic neurotransmission produces a persistent elevation of deltaFosB-like protein(s) in both the rodent and primate striatum. Eur J Neurosci 8:365-385.

Ehlers MD, Tingley WG, Huganir RL (1995) Regulated subcellular distribution of the NR1 subunit of the NMDA receptor. Science 269:1734-1737.

Fink M (1990) How does convulsive therapy work? Neuropsychopharmacology 3:73-82.

Fink M (1994) Optimizing ECT. Encephale 20:297-302.

Friedman LK, Pellegrini-Giampietro DE, Sperber EF, Bennett MVL, Moshe SL, Zukin RS (1994) Kainate-induced status epilepticus alters glutamate and $\mathrm{GABA}_{\mathrm{A}}$ receptor gene expression in adult rat hippocampus: an in situ hybridization study. J Neurosci 14:2697-2707.

Gabbott PLA, Dickie BGM, Vaid RR, Headlam AJN, Bacon SJ (1997) Local-circuit neurones in the medial prefrontal cortex (areas 25, 32 and 24b) in the rat: morphology and quantitative distribution. J Comp Neurol 377:465-499.

Gruda MC, van Amsterdam J, Rizzo CA, Durham SK, Lira S, Bravo R (1996) Expression of FosB during mouse development: normal development of FosB knockout mice. Oncogene 12:2177-2185.

Hess SD, Daggett LP, Crona J, Deal C, Lu C-C, Urrutia A, ChavezNoriega L, Ellis SB, Johnson EC, Velicelebi G (1996) Cloning and functional characterization of human heteromeric $N$-methyl-Daspartate receptors. J Pharmacol Exp Ther 278:808-816.

Hiroi N (1995) Compartmental organization of calretinin in the rat striatum. Neurosci Lett 197:223-226.

Hiroi N, Graybiel AM (1996) Atypical and typical neuroleptic treatments induce distinct programs of transcription factor expression in the striatum. J Comp Neurol 374:70-83.

Hiroi N, Chen J-S, Nestler EJ (1996) Chronic FRAs: novel transcription 
factors regulated in the basal ganglia by chronic neuronal perturbations. In: The basal ganglia V (Ohye C, Kimura M, McKenzie J, eds), pp 401-408. New York: Plenum.

Hiroi N, Brown JR, Haile CN, Ye H, Greenberg ME, Nestler EJ (1997) Fos B mutant mice: loss of chronic cocaine induction of Fos-related proteins and heightened sensitivity to cocaine's psychomotor and rewarding effects. Proc Natl Acad Sci USA 94:10397-10402.

Hope BT, Kosofsky B, Hyman SE, Nestler EJ (1992) Regulation of immediate early gene expression and AP-1 binding in the rat nucleus accumbens by chronic cocaine. Proc Natl Acad Sci USA 89:5764-5768.

Hope BT, Nye HE, Kelz MB, Self DW, Iadarola MJ, Nakabeppu Y, Duman RS, Nestler EJ (1994a) Induction of a long-lasting AP-1 complex composed of altered Fos-like proteins in brain by chronic cocaine and other chronic treatments. Neuron 13:1235-1244.

Hope BT, Kelz MB, Duman RS, Nestler EJ (1994b) Chronic electroconvulsive seizure (ECS) treatment results in expression of a longlasting AP-1 complex in brain with altered composition and characteristics. J Neurosci 14:4318-4328.

Hughes P, Dragunow M (1995) Induction of immediate-early genes and the control of neurotransmitter-regulated gene expression within the nervous system. Pharmacol Rev 47:133-178.

Hummler E, Cole TJ, Blendy JA, Ganss R, Aguzzi A, Schmid W, Beermann F, Schutz G (1994) Targeted mutation of the CREB gene: compensation within the CREB/ATF family of transcription factors. Proc Natl Acad Sci USA 91:5647-5651.

Huntley GW, Vickers JC, Janssen W, Brose N, Heinemann SF, Morrison JH (1994) Distribution and synaptic localization of immunocytochemically identified NMDA receptor subunit proteins in sensorymotor and visual cortices of monkey and human. J Neurosci 14:3603-3619.

Hyman SE, Nestler EJ (1993) The molecular foundations of psychiatry. Washington, DC: American Psychiatric.

Ishii T, Moriyoshi K, Sugihara H, Sakurada K, Kadotani H, Yokoi M, Akazawa C, Shigemoto R, Mizuno N, Masu M, Nakanishi S (1993) Molecular characterization of the family of the $N$-methyl-D-aspartate receptor subunits. J Biol Chem 268:2836-2843.

Kaminska B, Mosieniak G, Gierdalski M, Kossut M, Kaczmarek L (1995) Elevated AP-1 transcription factor DNA binding activity at the onset of functional plasticity during development of rat sensory cortical areas. Mol Brain Res 33:295-304.

Kawaguchi Y, Kubota Y (1997) GABAergic cell subtypes and their synaptic connections in rat frontal cortex. Cereb Cortex 7:476-486.

Korner M, Rattner A, Mauxion F, Sen R, Citri Y (1989) A brain-specific transcription activator. Neuron 3:563-572.

Kubota Y, Hattori R, Yui Y (1994) Three distinct subpopulations of GABA-ergic neurons in rat frontal aganular cortex. Brain Res 649:159-173.

Mandelzys A, Gruda MA, Bravo R, Morgan JI (1997) Absence of a persistently elevated $37 \mathrm{kDa}$ Fos-related antigen and AP-1-like DNAbinding activity in the brains of kainic acid-treated fos $\mathrm{B}$ null mice. J Neurosci 17:5407-5415.

Marks MJ, Grady SR, Collins AC (1993) Downregulation of nicotinic receptor function after chronic nicotine infusion. J Pharmacol Exp Ther 266:1268-1276.

McCormick DA, Connors BW, Lighthall JW, Prince DA (1985) Comparative electrophysiology of pyramidal and sparsely spiny stellate neurons of the neocortex. J Neurophysiol 54:782-806.

McNamara JO (1994) Cellular and molecular basis of epilepsy. J Neurosci 14:3413-3425.

Monyer H, Sprengel R, Schoepfer R, Herb A, Higuchi M, Lomeli H, Burnashev N, Sakmann B, Seeberg PH (1992) Heteromeric NMDA receptors: molecular and functional distinction of subtypes. Science 256:1217-1221.

Moratalla R, Elibol B, Vallejo M, Graybiel AM (1996) Network-level changes in expression of inducible Fos-Jun proteins in the striatum during chronic cocaine treatment and withdrawal. Neuron 17:147-156.

Morgan JI, Curran T (1991a) Stimulus-transcription coupling in the nervous system: involvement of the inducible proto-oncogenes fos and jun. Annu Rev Neurosci 14:421-451.

Morgan JI, Curran T (1991b) Proto-oncogene transcription factors and epilepsy. Trends Pharmacol 12:343-349.

Mumberg D, Lucibello FC, Schuermann M, Muller R (1991) Alternative splicing of $f o s B$ transcripts results in differentially expressed mRNAs encoding functionally antagonistic proteins. Genes Dev 5:1212-1223.
Nakabeppu Y, Nathans D (1991) A naturally occurring truncated form of FosB that inhibits Fos/Jun transcriptional activity. Cell 64:751-759.

Nakanishi S (1992) Molecular diversity of glutamate receptors and implications for brain function. Science 258:597-603.

Nibuya M, Nestler EJ, Duman RS (1996) Chronic antidepressant administration increases the expression of CREB in rat hippocampus. J Neurosci 16:2365-2372.

Nomikos GG, Mathe AA, Mathe JM, Svensson TH (1992) MK-801 prevents the enhanced behavioural response to apomorphine elicited by repeated electroconvulsive treatment in mice. Psychopharmacology (Berl) 108:367-370.

Nye HE, Nestler EJ (1996) Induction of chronic Fos-related antigens in rat brain by chronic morphine administration. Mol Pharmacol 49:636-645.

Nye HE, Hope BT, Kelz MB, Iadarola MJ, Nestler EJ (1995) Pharmacological studies of the regulation of chronic Fos-related antigen induction by cocaine in the striatum and nucleus accumbens. J Pharmacol Exp Ther 275:1671-1680.

Pennypacker KR, Thai L, Hong JS, McMillian MK (1994) Prolonged expression of AP-1 transcription factors in the rat hippocampus after systemic kainate treatment. J Neurosci 14:3998-4006.

Pennypacker KR, Hong J-S, McMillian MK (1995) Implications of prolonged expression of Fos-related antigens. Trends Pharmacol 16:317-321.

Pich EM, Pagliusi SR, Tessari M, Talabot-Ayer D, Hooft van Huijsduijnen R, Chiamulera C (1997) Common neural substrates for the addictive properties of nicotine and cocaine. Science 275:83-86.

Sasner M, Buonanno A (1996) Distinct $N$-methyl-D-aspartate receptor 2B subunit gene sequences confer neural and developmental specific expression. J Biol Chem 271:21316-21322.

Sheng M, Greenberg ME (1990) The regulation and function of c-fos and other immediate early genes in the nervous system. Neuron 4:477-485.

Sheng M, Cummings J, Roldan LA, Jan YN, Jan LY (1994) Changing subunit composition of heteromeric NMDA receptors during development of rat cortex. Nature 368:144-147.

Siegel SJ, Brose N, Janssen WG, Gasic GP, Jahn R, Heinemann SF, Morrison JH (1994) Regional, cellular, and ultrastructural distribution of the glutamate receptor subunit NMDAR1 in monkey hippocampus. Proc Natl Acad Sci USA 91:564-568.

Snell LD, Nunley KR, Lickteig RL, Browning MD, Tabakoff B, Hoffman PL (1996) Regional and subunit specific changes in NMDA receptor mRNA and immunoreactivity in mouse brain following chronic ethanol ingestion. Mol Brain Res 40:71-78.

Sonnenberg JL, Macgregor-Leon PF, Curran T, Morgan JI (1989) Dynamic alterations occur in the levels and composition of transcription factor AP-1 complexes after seizure. Neuron 3:359-365.

Stern P, Behe P, Schoepfer R, Colquhoun D (1992) Single-channel conductances of NMDA receptors expressed from cloned cDNAs: comparison with native receptors. Proc R Soc Lond [Biol] 250:271-277.

van Brederode JFM, Helliesen MK, Hendrickson AE (1991) Distribution of the calcium-binding proteins parvalbumin and calbindin-D28k in the sensorimotor cortex of the rat. Neuroscience 44:157-171.

Watanabe Y, Johnson RS, Butler LS, Binder DK, Spiegelman BM, Papaioannou VE, McNamara JO (1996) Null mutation of c-fos impairs structural and functional plasticities in the kindling model of epilepsy. J Neurosci 16:3827-3836.

Winston SM, Hayward MD, Nestler EJ, Duman RS (1990) Chronic electroconvulsive seizures down-regulate expression of the immediateearly genes c-fos and c-jun in rat cerebral cortex. J Neurochem 54:1920-1925.

Xu M, Moratalla R, Gold LH, Hiroi N, Koob GF, Graybiel AM, Tonegawa S (1994) Dopamine D1 receptor mutant mice are deficient in striatal expression of dynorphin and in dopamine-mediated behavioral responses. Cell 79:729-742.

Yen J, Wisdom RM, Tratner I, Verma IM (1991) An alternative spliced form of FosB is a negative regulator of transcriptional activation and transformed by Fos products. Proc Natl Acad Sci USA 88:5077-5081.

Young ST, Porrino LJ, Iadarola MJ (1991) Cocaine induces striatal c-Fos-immunoreactive proteins via dopaminergic D1 receptors. Proc Natl Acad Sci USA 88:1291-1295. 